\title{
Estimation of atmospheric turbidity over Ghardaïa city
}

\author{
D. Djafer ${ }^{\mathrm{a}}, \mathrm{A} . \mathrm{Irbah}^{\mathrm{b}}$ \\ ${ }^{a}$ Unité de Recherche Appliquée en Energies Renouvelables, URAER, Centre de Développement des Energies Renouvelables, CDER, 47133, Ghardaïa,Algeria \\ ${ }^{b}$ Laboratoire Atmosphères, Milieux, Observations Spatiales (LATMOS), CNRS : UMR8190 - Université Paris VI - Pierre et Marie Curie - Université de Versailles \\ Saint-Quentin-en-Yvelines - INSU, 78280, Guyancourt, France
}

\begin{abstract}
The atmospheric turbidity expresses the attenuation of the solar radiation that reaches the Earth's surface under cloudless sky and describes the optical thickness of the atmosphere. We investigate the atmospheric turbidity over Ghardaïa city using two turbidity parameters, the Linke turbidity factor and the Angström turbidity coefficient. Their values and temporal variation are obtained from data recorded between 2004 and 2008 at Ghardaïa. The results show that both parameters have the same trend along the year. They reach their maximum around summer months and their minimum around winter months. The monthly average value varies between 1.3 and 5.6 for the Linke turbidity factor and between 0.02 and 0.19 for the Angström turbidity coefficient. We find that $39.8 \%$ of the Linke turbidity factor values are less than $3,47.5 \%$ are between 3 and 5 and only $12.7 \%$ are greater than 5 . For the Angström turbidity coefficient, $9.4 \%$ of the values are less than $0.02,75.4 \%$ are between 0.02 and 0.15 and $15.2 \%$ exceed 0.15 .
\end{abstract}

Keywords: solar radiation, turbidity parameters, Linke factor, Angström coefficient.

\section{Introduction}

The quality and quantity of the solar radiation in a given ground site should be considered before installing solar energy conversion systems. Photovoltaic and solar thermal energy systems are usually designed considering their performance in standard test conditions and without taking into account local atmospheric ones (Malik, 2000). The reason is often the nonavailability of atmospheric data for a specific location when the solar systems are designed. It is nevertheless essential that variations of solar cell/module efficiency in various atmospheric turbidity and weather conditions are known to optimize their performances since an increase in turbidity reduces the output current of solar cells (Malik, 2000). Solar irradiance at ground level is strongly dependent on the Earth's atmosphere. Its constituents (aerosols, water vapor, ...etc) absorb and diffuse significantly the direct solar radiation. Thus, it is important to quantify their temporal effects when recording solar radiation measurements in a local area. This will helps in the future to establish models and accurately estimate the clear sky radiation. Among several turbidity parameters, the most frequently used are the Linke turbidity factor (Linke, 1922) and the Angström turbidity coefficient (Angström, 1961). As already mentioned before, the knowledge of these turbidity parameters is important to optimize the performances of solar radiation devices installed at a particular location but it is also important (i) in climate modeling and in pollution studies (Trabelsi and Masmoudi, 2011), (ii) to predict the availability of solar energy

\footnotetext{
${ }^{*}$ Principal corresponding author

${ }^{* *}$ Corresponding author

Email addresses: djdjafer@gmail.com (D. Djafer ), air@latmos.ipsl.fr (A. Irbah )
}

Preprint submitted to Atmospheric Research under cloudless skies essential for the design of solar thermal power plants and other solar energy conversion devices with concentration systems, (iii) to compute the amount of spectral global irradiance for the design of photovoltaic systems and calculation of the photosynthetic energy for plant growth (Malik, 2000).

In the present work, we will use five years of data daily recorded between 2004 and 2008 to study the turbidity of the atmosphere over Ghardaïa city. It is the first time to our knowledge that this kind of data and results covering a long period are presented for this particular region. We will recall at first the definition of the Linke turbidity factor and the Angström turbidity coefficient. We will then present the data used for this study and discuss the obtained results.

\section{The Linke turbidity factor}

The Linke turbidity factor $T_{l}$ has been used since 1922 to quantify atmospheric turbidity conditions. It is defined as the number of clean dry atmospheres necessary to have the same attenuation of the extraterrestrial radiation produced by the real atmosphere (Trabelsi and Masmoudi, 2011). The Linke turbidity factor is useful for modeling the atmospheric absorption and scattering of the solar radiation during clear skies. The Linke factor depends on the air mass and most popular methods normalize the measured values of $T_{l}$ to an air mass equal to 2 (Grenier et al., 1994, Kasten, 1988). This turbidity factor describes the optical thickness of the atmosphere due to both the absorption and scattering by the water vapor and aerosol particles relatively to a dry and clean atmosphere. It expresses the atmosphere turbidity or equivalently the attenuation of the direct solar radiation flux. The value of the Linke factor may then be 
derived from the direct component of the solar irradiance (Chaiwiwatworakul et al., 1994, Ellouz et al., 2004, Mavromatakis and Franghiadakis, 2007, Trabelsi and Masmoudi, 2011, Zakey et al., 2004). Typical values of the Linke factor vary between 1 and 10. High values of the Linke factor mean that the solar radiations are more attenuated in a clear sky atmosphere. We use the following Equation to calculate the Linke factor $T_{l}$ (Mavromatakis and Franghiadakis, 2007, Trabelsi and Masmoudi, 2011):

$$
T_{l}=T_{l k} \frac{\frac{1}{\delta_{R a}\left(m_{a}\right)}}{\frac{1}{\delta_{R k}\left(m_{a}\right)}}
$$

$T_{l k}$ is the Linke factor according to Kasten (Kasten, 1980), $\delta_{R k}\left(m_{a}\right)$ the Rayleigh integral optical thickness and $\delta_{R a}\left(m_{a}\right)$ the integral optical thickness given by Louche et al. (1986) and adjusted by Kasten (1996). The subscript k stands for the author "Kasten" and the subscript $a$ for the word "adjusted". The Linke factor $T_{l k}$ is related to the normal incidence solar irradiance by the Equation (Kasten, 1980, Trabelsi and Masmoudi, 2011):

$$
T_{l k}=(0.9+9.4 \sin (h)) *\left(2 \ln \left(I_{0}\left(\frac{R_{0}}{R}\right)\right)-\ln \left(I_{n}\right)\right)
$$

where $h$ is the Sun's elevation angle in degrees, $I_{n}$ the direct normal solar irradiance at normal incidence and $I_{0}$ the solar constant $\left(1367 \mathrm{~W} / \mathrm{m}^{2}\right) . R$ and $R_{0}$ are respectively the instantaneous and mean Sun-Earth distances. The value of $I_{n}$ is measured directly through a pyrheliometer in $\left(\mathrm{W} / \mathrm{m}^{2}\right)$.

The expression of $\delta_{R k}\left(m_{a}\right)$ and $\delta_{R a}\left(m_{a}\right)$ are given by the following Equations:

$$
\begin{aligned}
& \frac{1}{\delta_{R a}}\left(m_{a}\right)=6.6296+1.7513 m_{a}-0.1202 m_{a}^{2} \\
&+0.0065 m_{a}^{3}-0.00013 m_{a}^{4} \\
& \frac{1}{\delta_{R k}}\left(m_{a}\right)=9.4+0.9 m_{a}
\end{aligned}
$$

where $m_{a}$ is the air mass given by:

$$
m_{a}=m_{r}\left(\frac{P}{101325}\right)
$$

The parameter $m_{r}$ is the air mass at the standard conditions (Canada et al., 1993) defined by:

$$
m_{r}=\left[\sin (h)+0.15(3.885+h)^{-1.253}\right]^{-1}
$$

The local pressure $P$ (in Pascal) is given by (Pinazo et al., 1995):

$$
P=101325 \exp (-0.0001184 z)
$$

where $\mathrm{z}$ is the altitude in meter of the location above sea level.

\section{The Angström coefficient}

The Angström coefficient $\beta$ is a measure of the presence of aerosols. It characterizes the amount of aerosol content in the vertical column of air with transversal unitary (Trabelsi and Masmoudi, 2011). The typical values of this parameter vary between 0 to 0.5 (Angström, 1961, 1964, Danny and Lam, 2002, Grenier et al., 1995, Gueymard and Garrison, 1998, Trabelsi and Masmoudi, 2011). Its minimum value (zero) refers to an ideally dust free atmosphere, while values superior to unity refer to an extremely turbid atmosphere. The Angström coefficient can be determined with different methods and spectral measurements (Jacovides et al., 2005, Kaskaoutis et al., 2008a, Kaskaoutis and Kambezidis, 2008b, Lopez and Batlles, 2004, Masmoudi et al., 2003, Trabelsi and Masmoudi, 2011, Zakey et al., 2004). We will compute the Angström coefficient using the empirical formula of Dogniaux (1974) since we have not a photometric instrument at Ghardaïa to discriminate aerosols by mean of spectral measurements. Many authors have used this formula to derive the Angström turbidity coefficient (Cucumo et al., 1999, Danny and Lam, 2002, Grenier et al., 1995, Janjai et al., 2003, Lopez and Batlles, 2004, Vida et al., 1999). This empirical formula is given by the following Equation:

$$
\beta=\frac{T_{l}-\left[\frac{h+85}{39.5 \exp \left(-w_{p}\right)+47.4}+0.1\right]}{16+0.22 w_{p}}
$$

where $h$ is the Sun's elevation angle in degrees and $w_{p}$ the precipitation amount in centimeter. The value of $w_{p}$ is calculated using the Equation (Leckner, 1978):

$$
w_{p}=0.493 \frac{\phi}{T} \exp \left(26.23-\frac{5416}{T}\right)
$$

where $T$ is the temperature in Kelvin and $\phi$ is the relative humidity in fractions of one.

Other models exist to calculate the Angström coefficient such as the models of Louche et al. (1986), of Pinazo et al. (1995) and of Gueymard and Vignola (1998). These models require some parameters that we have not at Ghardaïa for the period considered in this study. Such parameters are the wavelength exponent $\alpha$ that is used to calculate the aerosol transmittance, the ground albedo $\rho_{g}$, the forward scattering $F_{c}$ and the single scattering albedo $w_{0}$. Wen and Yeh (2009) have studied the atmospheric turbidity properties of Taichung Harbor considering data recorded in 2004-2005 and the Angström turbidity models of Louche et al. (1986) and Pinazo et al. (1995). They found that the annual mean values of the Angström turbidity coefficient obtained from theses models were respectively 0.174 and 0.21 .

\section{Site location and solar radiation data}

The data used to perform the present study have been recorded at the Applied Research Unit for Renewable Energies (URAER) situated in the south of Algeria far from Ghardaïa city of about $18 \mathrm{~km}$. The latitude, longitude and altitude of the 
Table 1: Monthly and annual average values of the temperature and humidity

\begin{tabular}{|c|c|c|c|c|c|c|c|c|c|c|}
\hline & \multicolumn{5}{|c|}{$\begin{array}{l}\text { TEMPERATURE } \\
\text { (Degree Celsius) }\end{array}$} & \multicolumn{5}{|c|}{$\begin{array}{c}\text { HUMIDITY } \\
(\%)\end{array}$} \\
\hline Month & 2004 & 2005 & 2006 & 2007 & 2008 & 2004 & 2005 & 2006 & 2007 & 2008 \\
\hline $\mathrm{J}$ & - & $13 \pm 3$ & $13 \pm 2$ & $17 \pm 2$ & $16 \pm 2$ & - & $39 \pm 8$ & $45 \pm 9$ & $40 \pm 9$ & $37 \pm 11$ \\
\hline $\mathrm{F}$ & - & $14 \pm 4$ & $16 \pm 3$ & $19 \pm 4$ & $18 \pm 3$ & - & $31 \pm 11$ & $37 \pm 11$ & $33 \pm 10$ & $29 \pm 8$ \\
\hline M & - & $21 \pm 6$ & $23 \pm 5$ & $19 \pm 3$ & $21 \pm 5$ & - & $24 \pm 8$ & $24 \pm 7$ & $26 \pm 8$ & $24 \pm 8$ \\
\hline A & - & $25 \pm 5$ & $27 \pm 4$ & $25 \pm 3$ & $25 \pm 5$ & - & $21 \pm 7$ & $23 \pm 11$ & $20 \pm 5$ & $18 \pm 8$ \\
\hline M & - & $33 \pm 4$ & $32 \pm 6$ & $32 \pm 4$ & $29 \pm 5$ & - & $12 \pm 3$ & $22 \pm 12$ & $15 \pm 5$ & $19 \pm 8$ \\
\hline $\mathrm{J}$ & $39 \pm 2$ & $36 \pm 4$ & $35 \pm 6$ & $35 \pm 7$ & $34 \pm 4$ & $15 \pm 3$ & $19 \pm 6$ & $12 \pm 8$ & $14 \pm 7$ & $19 \pm 8$ \\
\hline $\mathrm{J}$ & $37 \pm 1$ & $43 \pm 3$ & $38 \pm 3$ & $38 \pm 2$ & $41 \pm 3$ & $14 \pm 4$ & $10 \pm 5$ & $15 \pm 5$ & $14 \pm 5$ & $11 \pm 5$ \\
\hline A & $39 \pm 3$ & $37 \pm 4$ & $40 \pm 2$ & $38 \pm 3$ & - & $16 \pm 8$ & $19 \pm 11$ & $13 \pm 4$ & $17 \pm 8$ & - \\
\hline S & $32 \pm 4$ & $36 \pm 2$ & $33 \pm 3$ & $34 \pm 4$ & $33 \pm 4$ & $23 \pm 7$ & $20 \pm 6$ & $18 \pm 4$ & $22 \pm 9$ & $22 \pm 13$ \\
\hline $\mathrm{O}$ & $30 \pm 4$ & $28 \pm 2$ & $32 \pm 2$ & $28 \pm 5$ & $27 \pm 2$ & $23 \pm 7$ & $36 \pm 10$ & $18 \pm 4$ & $26 \pm 11$ & $38 \pm 10$ \\
\hline $\mathrm{N}$ & $18 \pm 3$ & $21 \pm 5$ & $22 \pm 4$ & $21 \pm 5$ & $15 \pm 5$ & $43 \pm 10$ & $30 \pm 7$ & $30 \pm 9$ & $28 \pm 10$ & $44 \pm 7$ \\
\hline D & $15 \pm 3$ & $15 \pm 3$ & $16 \pm 2$ & $15 \pm 3$ & $29 \pm 3$ & $46 \pm 6$ & $39 \pm 8$ & $46 \pm 9$ & $38 \pm 9$ & $25 \pm 17$ \\
\hline Mean & $30 \pm 3$ & $27 \pm 4$ & $27 \pm 3$ & $27 \pm 4$ & $26 \pm 5$ & $26 \pm 6$ & $25 \pm 7$ & $25 \pm 8$ & $24 \pm 8$ & $26 \pm 10$ \\
\hline
\end{tabular}

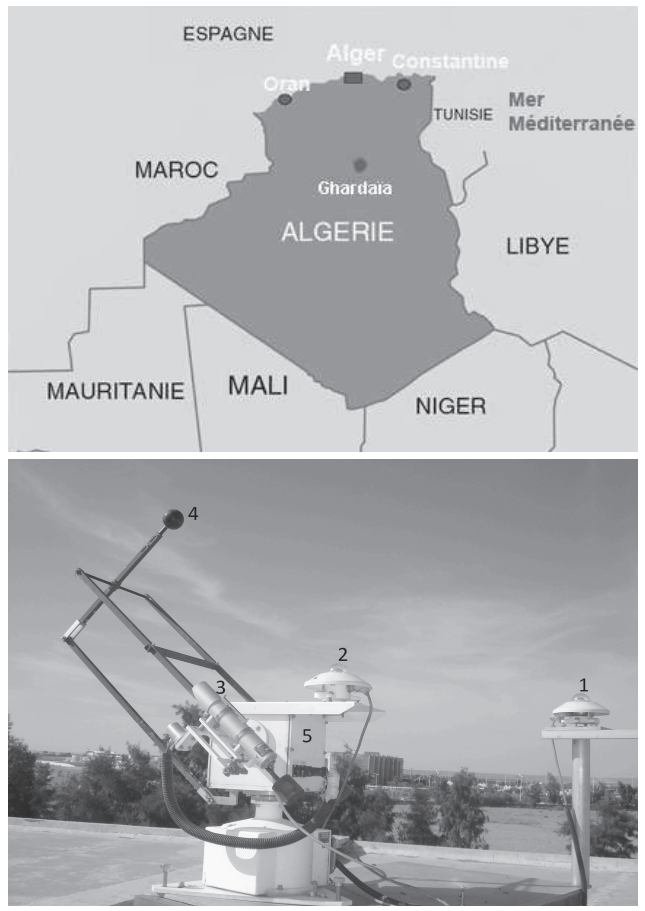

Figure 1: Location of Ghardaïa city (top). Instrumentation station (bottom) for measuring the global, the direct and the diffuse solar radiation: (1) Pyranometer for measuring the global solar irradiance. (2) Pyranometer for measuring the diffuse irradiance component. (3) Peryheliometer for measuring the direct irradiance component. (4) The ball used to permanently hide the pyranometer (2). (5) The 2-axis solar tracker.
URAER are respectively $+32.37^{\circ},+3.77^{\circ}$ and $450 \mathrm{~m}$ above the sea level (see the top of Figure 1). They are recorded every 5 minutes since 2004 and consist in data of temperature, humidity and of the direct and diffuse solar irradiance. The instruments that measure the direct, the global and the diffuse solar radiation components are of EKO type. They are shown at the bottom in Figure 1. The instrument (1) in the Figure is a pyranometer that measures the global solar irradiance. (2) is also a pyranometer that measures the diffuse irradiance component. It is permanently shaded from the direct normal irradiance by the black ball (4). The peryheliometer (3) measures the direct irradiance component. Both the black ball and the peryheliometer are mounted on the automatic 2-axis solar tracker (5). The radiometric instruments are usually cleaned two or three times per week following the weather conditions. They are also regularly calibrated at the meteorological station of Tamanrasset (latitude $=+22.78^{\circ}$, longitude $=+5.51^{\circ}$, altitude $=1270 \mathrm{~m}$ ) where the solar irradiance is measured since 1970. The last calibration process performed in 2010 showed a mean difference in the solar irradiance measurements within $1 \mathrm{~W} / \mathrm{m}^{2}$. The mean derive was respectively $1.3 \%$ and $0.6 \%$ for the global and diffuse solar irradiance given by the 2 pyranometers and it was $1.1 \%$ for the deduced value obtained from the peryheliometer.

Data recorded between 2004 and 2008 with the instrumentation station shown in Figure 1, are used to calculate the Linke factor and the Angström coefficient. Data are first selected considering only those that correspond to clear skies. The method of Long and Ackerman (2000) has been used for this goal. Only measurements that meet all the requirements imposed by the 

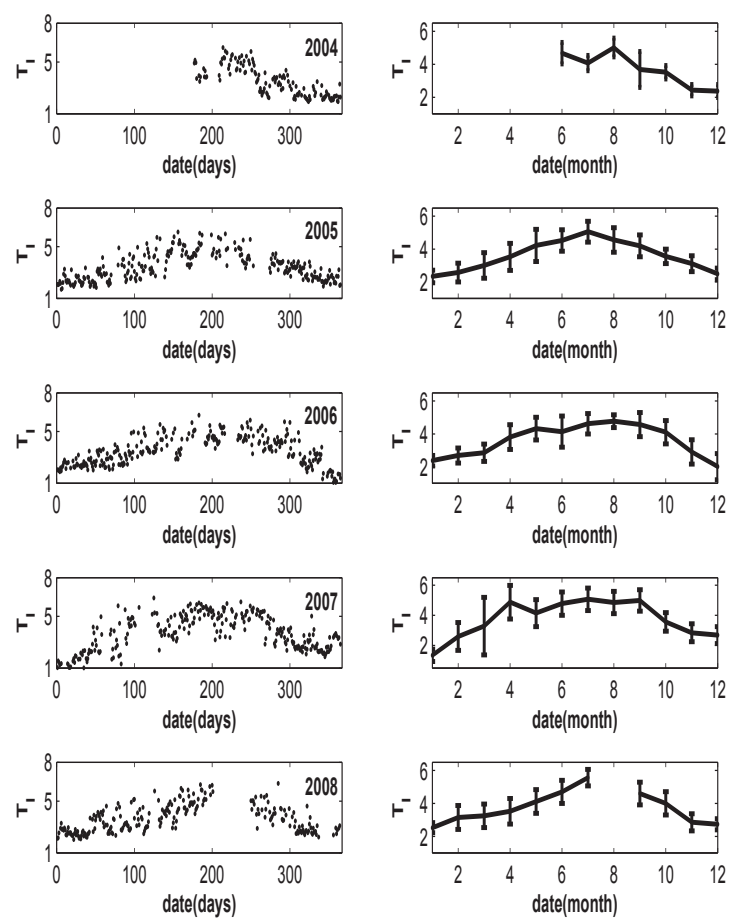

Figure 2: Daily (left part) and monthly (right part) variations of the Linke turbidity factor $T_{i n k}$ with the error bars.

four successive tests of the method are considered. $37 \%$ of the whole data set remains finally for the present study when applying the selection.

For the meteorological data, only the temperature and the humidity data are available for the considered period. The monthly and the annual average values of these two meteorological parameters are summarized in Table 1 . We note that the annual average values of the temperature and humidity are respectively $27^{\circ}$ and $25 \%$. The monthly average values are between $13^{\circ}$ and $43^{\circ}$ for the temperature and between $10 \%$ and $46 \%$ for the humidity. The predominant wind direction over Ghardaïa city is South-West according to information given by a meteorological station located at about 200 meters of our site.

\section{Results and discussion}

We use Equations (1) and (8) to calculate the Linke turbidity factor and the Angström turbidity coefficient. Some algorithms were needed and developed to determine the ephemerides necessary to perform these calculations. The monthly and the annual average values of the Linke factor and the Angström coefficient are given in Table 2. The daily and monthly variations of these two parameters are shown in Figures 2 and 3. We can note that they show the same trend along the year and have their maximum and minimum values respectively during the summer and winter months. This can be explained by a hot summer climate and winds of the south sectors (Sirocco) that
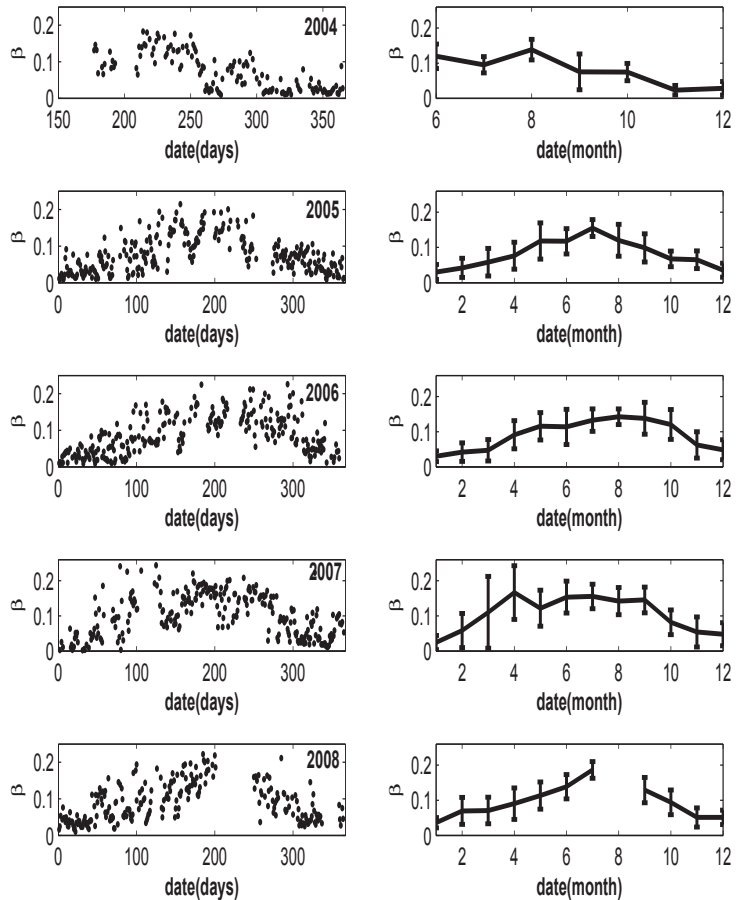

Figure 3: Daily (left part) and monthly (right part) variations of the Angström coefficient $\beta$ with the error bars.

characterize the region of Ghardaïa. This kind of winds brings particles of dust and sand with them, which leads to increase the Linke factor and the Angström coefficient (Bouhadda and Serrir, 2009). The period of winter is characterized by rains that wash the atmosphere and thus contribute to diminish both turbidity variables. In fact, the monthly average of rainfall amount
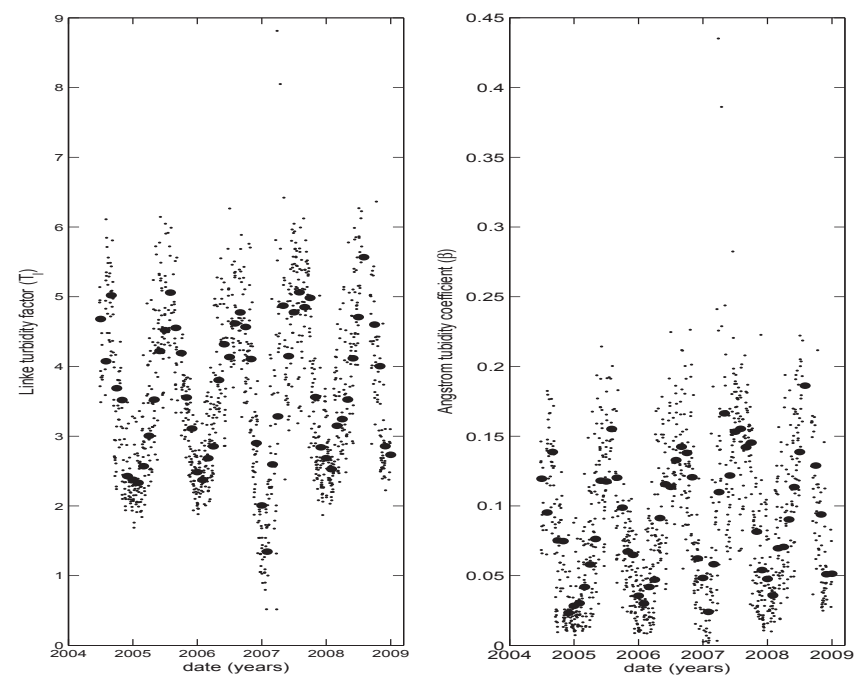

Figure 4: Seasonal variation of the Linke turbidity factor (left part) and the Angström turbidity coefficient (right part). The points are the daily variations while the circles are the monthly ones. 
Table 2: Monthly and annual average values of the Linke turbidity factor and the Angstrom coefficient

\begin{tabular}{|c|c|c|c|c|c|c|c|c|c|c|}
\hline & \multicolumn{5}{|c|}{ LINKE TURBIDITY FACTOR } & \multicolumn{5}{|c|}{ ANGSTRÖM TURBIDITY COEFFICIENT } \\
\hline $\mathrm{J}$ & - & $2.3 \pm 0.4$ & $2.4 \pm 0.3$ & $1.3 \pm 0.4$ & $2.5 \pm 0.3$ & - & $0.03 \pm 0.02$ & $0.03 \pm 0.02$ & $0.02 \pm 0.02$ & $0.04 \pm 0.02$ \\
\hline $\mathrm{F}$ & - & $2.6 \pm 0.6$ & $2.7 \pm 0.5$ & $2.6 \pm 0.9$ & $3.2 \pm 0.7$ & - & $0.04 \pm 0.03$ & $0.04 \pm 0.03$ & $0.06 \pm 0.05$ & $0.07 \pm 0.04$ \\
\hline $\mathrm{M}$ & - & $3.0 \pm 0.8$ & $2.9 \pm 0.5$ & $3.3 \pm 1.9$ & $3.3 \pm 0.7$ & - & $0.06 \pm 0.04$ & $0.05 \pm 0.03$ & $0.11 \pm 0.10$ & $0.07 \pm 0.04$ \\
\hline A & - & $3.5 \pm 0.8$ & $3.8 \pm 0.8$ & $4.9 \pm 1.1$ & $3.5 \pm 0.8$ & - & $0.08 \pm 0.04$ & $0.09 \pm 0.04$ & $0.17 \pm 0.08$ & $0.09 \pm 0.05$ \\
\hline $\mathrm{M}$ & - & $4.2 \pm 1.0$ & $4.3 \pm 0.7$ & $4.2 \pm 0.9$ & $4.1 \pm 0.7$ & - & $0.12 \pm 0.05$ & $0.12 \pm 0.04$ & $0.12 \pm 0.05$ & $0.11 \pm 0.04$ \\
\hline $\mathrm{J}$ & $4.7 \pm 0.7$ & $4.5 \pm 0.7$ & $4.1 \pm 1.0$ & $4.8 \pm 0.8$ & $4.7 \pm 0.7$ & $0.12 \pm 0.04$ & $0.12 \pm 0.04$ & $0.11 \pm 0.05$ & $0.15 \pm 0.05$ & $0.14 \pm 0.03$ \\
\hline $\mathrm{J}$ & $4.1 \pm 0.5$ & $5.1 \pm 0.6$ & $4.6 \pm 0.6$ & $5.1 \pm 0.8$ & $5.6 \pm 0.5$ & $0.10 \pm 0.02$ & $0.16 \pm 0.02$ & $0.13 \pm 0.03$ & $0.16 \pm 0.04$ & $0.19 \pm 0.02$ \\
\hline A & $5.0 \pm 0.6$ & $4.6 \pm 0.8$ & $4.8 \pm 0.4$ & $4.9 \pm 0.7$ & - & $0.14 \pm 0.03$ & $0.12 \pm 0.05$ & $0.14 \pm 0.02$ & $0.14 \pm 0.04$ & - \\
\hline $\mathrm{S}$ & $3.7 \pm 1.1$ & $4.2 \pm 0.7$ & $4.6 \pm 0.7$ & $5.0 \pm 0.7$ & $4.6 \pm 0.7$ & $0.08 \pm 0.05$ & $0.10 \pm 0.04$ & $0.14 \pm 0.05$ & $0.15 \pm 0.04$ & $0.13 \pm 0.04$ \\
\hline $\mathrm{O}$ & $3.5 \pm 0.4$ & $3.6 \pm 0.4$ & $4.1 \pm 0.7$ & $3.6 \pm 0.6$ & $4.0 \pm 0.7$ & $0.08 \pm 0.03$ & $0.07 \pm 0.02$ & $0.12 \pm 0.04$ & $0.08 \pm 0.04$ & $0.09 \pm 0.04$ \\
\hline $\mathrm{N}$ & $2.4 \pm 0.3$ & $3.1 \pm 0.5$ & $2.9 \pm 0.8$ & $2.8 \pm 0.6$ & $2.9 \pm 0.5$ & $0.02 \pm 0.01$ & $0.07 \pm 0.03$ & $0.06 \pm 0.04$ & $0.05 \pm 0.04$ & $0.05 \pm 0.03$ \\
\hline $\mathrm{D}$ & $2.4 \pm 0.4$ & $2.5 \pm 0.4$ & $2.0 \pm 0.8$ & $2.7 \pm 0.6$ & $2.7 \pm 0.3$ & $0.03 \pm 0.02$ & $0.04 \pm 0.02$ & $0.05 \pm 0.03$ & $0.05 \pm 0.03$ & $0.05 \pm 0.02$ \\
\hline Mean & $3.7 \pm 0.6$ & $3.6 \pm 0.6$ & $3.6 \pm 0.6$ & $3.8 \pm 0.8$ & $3.7 \pm 0.6$ & $0.08 \pm 0.03$ & $0.08 \pm 0.03$ & $0.09 \pm 0.03$ & $0.11 \pm 0.05$ & $0.09 \pm 0.03$ \\
\hline
\end{tabular}

at Ghardaïa for the last six months of the year is $1 \mathrm{~mm}$ in July, $1 \mathrm{~mm}$ in August, $4 \mathrm{~mm}$ in September, $5 \mathrm{~mm}$ in October, $13 \mathrm{~mm}$ in November and $7 \mathrm{~mm}$ in December.

The variation of the Linke turbidity factor and Angström turbidity coefficient during the whole period 2004 to 2008 is represented in Figure 4. We find that the monthly average value varied between 1.3 and 5.6 for the Linke turbidity factor and between 0.02 and 0.19 for the Angström turbidity coefficient. The time variations of the two turbidity parameters were approximated for each year with sixth degree polynomial functions to study how their maximum values have changed over the years (see Figure 5). The coefficients of the polynomial functions
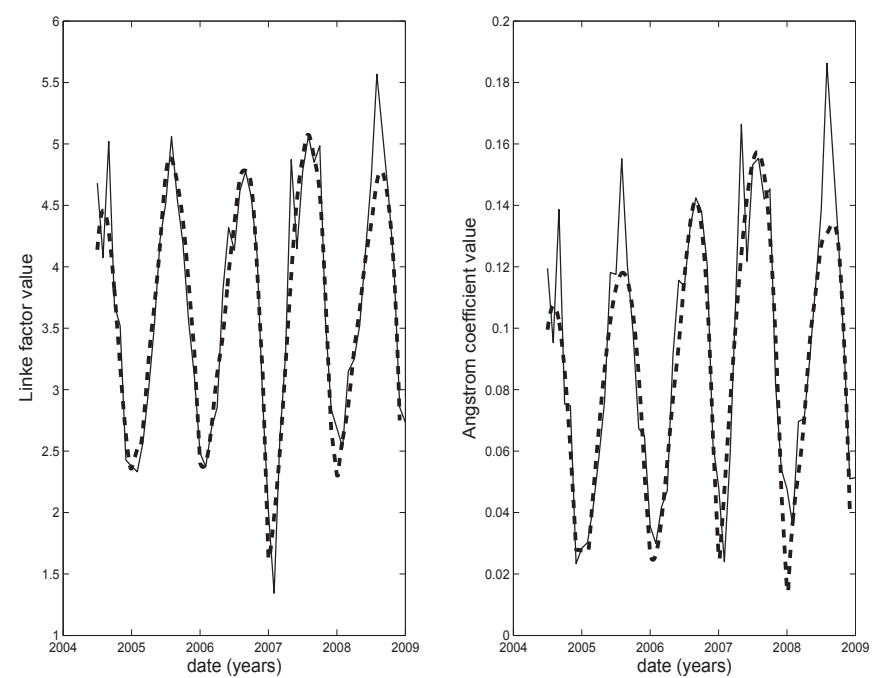

Figure 5: Seasonal variation of the Linke turbidity factor (left part - solid line) and the Angström turbidity coefficient (right part - solid line) approximated with sixth order polynomial functions (dashed line). used in the approximation are given in the Appendix. For each year, the approximation is of good quality since the root mean square error (rmse) is about 0.18 for the Linke factor values and 0.01 for the Angstrom coefficient ones. The applicability of this polynomial regression is however limited to filling some gaps in the data series. We found that the annual maximum values of the Linke factor and the Angström coefficient have both the same trend on the considered period (2004 to 2008). The maximum values of both parameters occur during July and August months. The time shifts of the annual maximum val-
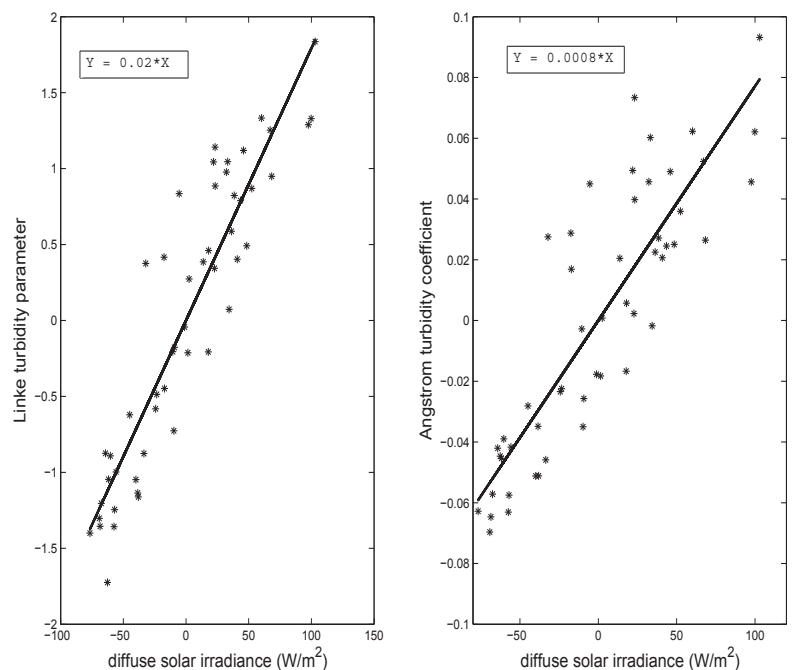

Figure 6: The monthly values of the Linke factor (left part) and the Angström coefficient (right part) versus the monthly values of the diffuse solar irradiance with their linear regression equations. 
ues have also been studied considering the middle of the year as reference (July, 1st). We found time shifts up to 2 months during the period 2004 to 2008. Moreover, the correlation of the two turbidity parameters with the diffuse solar irradiance is analyzed. We can observe a strong correlation between them as shown in Figure 6 where we have plotted the monthly values of the Linke factor and the Angström coefficient versus the diffuse solar irradiance. Their mean value has been subtracted leading to directly deduce the correlation factor from the slope of the fitted straight line in the curves. We find a correlation factor of 0.92 between the Linke factor and the diffuse solar irradiance and 0.87 for the Angström coefficient.

We have finally performed a statistical analysis by computing the histograms of the values of the Linke turbidity factor and of the Angstöm coefficient. They are shown in Figure 7 where we can notice that $39.8 \%$ of the Linke turbidity factor values are less than $3,47.5 \%$ are between 3 and 5 and only $12.7 \%$ are greater than 5 . For the Angström turbidity coefficient, $9.4 \%$ of the values are less than $0.02,75.4 \%$ are between 0.02 and 0.15 and $15.2 \%$ exceed 0.15 . We have compared our results with those obtained by Trabelsi and Masmoudi (2011) who studied the atmospheric turbidity over the city of Sidi Bou Saïd in Tunisia (latitude $+36.87^{\circ}$, longitude $+10.35^{\circ}$, altitude: $130 \mathrm{~m}$ ). It is at a latitude approaching that of Ghadaïa but located at a lower altitude. Trabelsi and Masmoudi used the same method as our to compute the two turbidity parameters taking data recorded on the site between July 2008 and June 2009. They showed that about $68 \%$ of the Angström coefficient values ranged between 0.02 and 0.1 and $7 \%$ of the values were greater than 0.15 . For the Linke factor, $66 \%$ of the values were between 3 and 5 and only $27 \%$ of them were greater than 5 . We may notice that the results are similar with ours but with a turbidity lower in Ghardaïa city. It should be noted however, that only one year of measurements was used to perform the turbidity analysis at Sidi Bou Saïd while we have considered a period of five years in our study.

\section{Conclusion}

Five years of data recorded between 2004 and 2008 at the URAER (Applied Research Unit for Renewable Energies) were used to study the turbidity of the atmosphere over the region of Ghardaïa by means of two parameters, the Linke turbidity factor and the Angström coefficient. The results reveal that the two parameters have the same behavior along the year. A maximum attenuation by the Earth's atmosphere of the solar radiations recorded at the ground level is observed in summer and reciprocally a minimum in winter. This seasonal trend is related to the climate of the region which is characterized in summer by a hot weather and Sirocco winds that bring dust and sand particles and in winter by a dry weather and rains. The occurrence date of the annual maximum values of both turbidity parameters change however over the years. The time shift may be up to 2 months relatively to the middle of the year (July 1st). We find also that the monthly parameter values are strongly correlated with the diffuse solar irradiance. The results we obtain for the
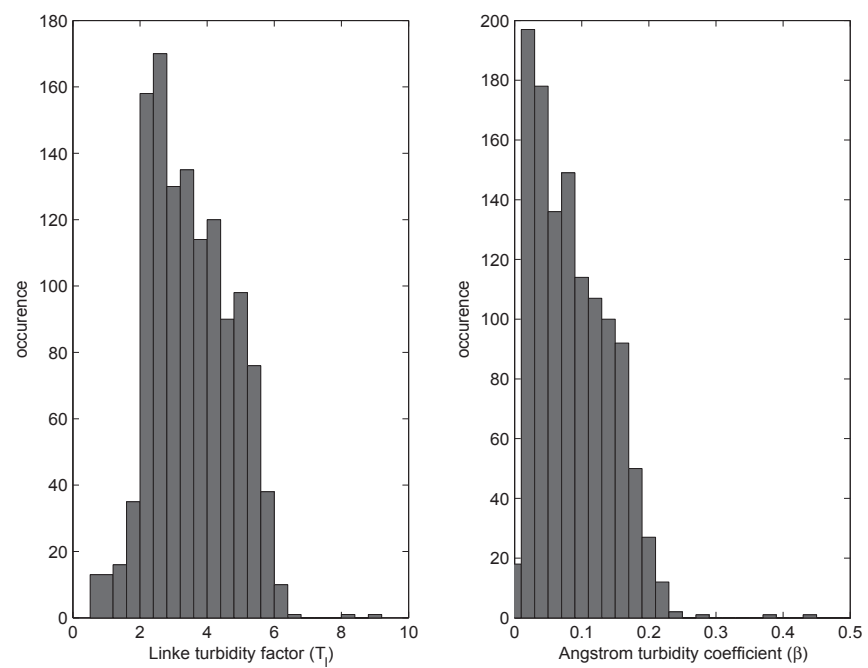

Figure 7: Histogram of the values of the Linke factor (left part) and the Angström coefficient (right part) obtained on a period of the five years.

Linke turbidity factor and the Angström coefficient at Ghardaïa, have been compared with those deduced from a similar study performed over the Sidi Bou Saïd city in Tunisia. We find results very close but with lower turbidity conditions at Ghardaïa. The analysis period considered for the Sidi Bou Saïd study is however only one year.

The present study is a preliminary work that asks now for developing models to better explain the obtained results for the Ghardaiia region and to understand the evolution of both the Linke factor and the Angström coefficient during a long time period. We need also to analyze how the used models may affect the estimation of the two parameters. Nevertheless, the results of both parameters reported in the present paper may be used to (i) design and check the performance of solar devices of any locality that have a similar climate to Ghardaiia, (ii) to investigate/study the variation of efficiency of solar devices with the variation in the spectrum of incident radiation, (iii) to have a reference point for global studies of the evolution of atmosphere turbidity and aerosols.

\section{Acknowledgements}

We would like to thank and acknowledge the support of the team at the Research Unit on Renewable Energies of Ghardaïa whose collected the data used in the present study.

\section{References}

Angström A., 1961. Techniques of determining the turbidity of the atmosphere. Tellus 13, 214-223.

Angström A., 1964. The parameters of atmospheric turbidity. Tellus 16, 64-75. Bouhadda Y. and Serrir L., 2006. Contribution à l'étude du trouble atmosphérique de Linke sur le site de Ghardaïa. Revue des Energies Renouvelables 9, 277-284.

Canada J., Pinazo J.M. and Boscá, J.V, 1993. Determination of Angström's turbidity coefficient at Valencia. Renewable Energy 3, 6/7, 621-626.

Chaiwiwatworakul P. and Chirarattananon, S., 2004. An investigation of atmospheric turbidity of Thai sky. Energy and Buildings 36, 650-659. 
Table 3: Coefficients of the sixth order polynomial function for the Linke turbidity factor

\begin{tabular}{cccccccc}
\hline Year & $a_{6}$ & $a_{5}$ & $a_{4}$ & $a_{3}$ & $a_{2}$ & $a_{1}$ & $a_{0}$ \\
\hline 2004 & 0 & 0 & 0 & $5.327 \mathrm{e}+01$ & $-3.204 \mathrm{e}+05$ & $6.423 \mathrm{e}+08$ & $-4.292 \mathrm{e}+11$ \\
2005 & $1.475 \mathrm{e}-06$ & $-5.222 \mathrm{e}-03$ & $3.574 \mathrm{e}-02$ & $-2.831 \mathrm{e}+04$ & $2.326 \mathrm{e}+08$ & $-4.575 \mathrm{e}+11$ & $2.831 \mathrm{e}+14$ \\
2006 & $1.747 \mathrm{e}-06$ & $-1.557 \mathrm{e}-02$ & $4.190 \mathrm{e}+01$ & $8.236 \mathrm{e}+03$ & $-2.288 \mathrm{e}+08$ & $3.857 \mathrm{e}+11$ & $-2.060 \mathrm{e}+14$ \\
2007 & $1.005 \mathrm{e}-06$ & $-7.663 \mathrm{e}-03$ & $2.845 \mathrm{e}+01$ & $-8.225 \mathrm{e}+04$ & $1.825 \mathrm{e}+08$ & $-2.335 \mathrm{e}+11$ & $1.205 \mathrm{e}+14$ \\
2008 & $-1.263 \mathrm{e}-06$ & $7.806 \mathrm{e}-03$ & $-2.274 \mathrm{e}+01$ & $7.239 \mathrm{e}+04$ & $-2.101 \mathrm{e}+08$ & $3.172 \mathrm{e}+11$ & $-1.783 \mathrm{e}+14$ \\
\hline
\end{tabular}

Table 4: Coefficients of the sixth order polynomial function for the Angström turbidity coefficient

\begin{tabular}{cccccccc}
\hline Year & $a_{6}$ & $a_{5}$ & $a_{4}$ & $a_{3}$ & $a_{2}$ & $a_{1}$ & $a_{0}$ \\
\hline 2004 & 0 & 0 & 0 & $5.320 \mathrm{e}-01$ & $-3.200 \mathrm{e}+03$ & $6.417 \mathrm{e}+06$ & $-4.289 \mathrm{e}+09$ \\
2005 & 0 & 0 & 0 & $-3.539 \mathrm{e}-01$ & $2.129 \mathrm{e}+03$ & $-4.268 \mathrm{e}+06$ & $2.853 \mathrm{e}+09$ \\
2006 & $5.854 \mathrm{e}-09$ & $-1.236 \mathrm{e}-04$ & $3.084 \mathrm{e}-01$ & $1.555 \mathrm{e}+03$ & $-8.245 \mathrm{e}+06$ & $1.322 \mathrm{e}+10$ & $-7.254 \mathrm{e}+12$ \\
2007 & 0 & 0 & 0 & $-5.266 \mathrm{e}-01$ & $3.171 \mathrm{e}+03$ & $-6.364 \mathrm{e}+06$ & $4.258 \mathrm{e}+09$ \\
2008 & $-6.825 \mathrm{e}-08$ & $5.567 \mathrm{e}-04$ & $-2.394 \mathrm{e}+00$ & $7.832 \mathrm{e}+03$ & $-1.770 \mathrm{e}+07$ & $2.199 \mathrm{e}+10$ & $-1.097 \mathrm{e}+13$ \\
\hline
\end{tabular}

Cucumo M., Marinelli V. and Oliveti G., 1999. Experimental data of the Linke turbidity factor and estimates of the turbidity coefficient for two Italian localities. Renewable Energy 17, 397-410.

Danny H.W.Li and Joseph C.Lam., 2002. A study of atmosphere turbidity for Honh Kong. Renewable Energy 25, 1-13.

Dogniaux R., 1974. Repréntations analytiques des composantes du rayonnement lumineux solaire. Conditions du ciel serein. Institut Royal de Métiorologie de Belgique, Série A No. 83, 3-24.

Ellouz F., Masmoud M. and Medhioub K., 2008. Study of the atmospheric turbidity over Northern Tunisia. Renewable Energy 2, 1-5.

Grenier J. C., De La Casiniere A. and Cabot T., 1994. A spectral model of Linke's turbidity factor and its experimental implications. Solar Energy 52, 303-314.

Grenier J.C., Casiniere A. and Cabo T.T., 1995. Atmospheric turbidity analyzed by means of standardized Linke's factor. Journal of Applied Meteorology $34,1449-1458$

Gueymard C.A. and Garrison J.D. (1998) Critical evaluation of precipitable water and atmospheric turbidity in Canada using measured hourly solar irradiance. Solar Energy 62 (4), 291-307.

Gueymard C. and Vignola F., 1998. Determination of atmospheric turbidity from the diffuse-beam broadband irradiance ratio. Solar Energy 63 (3), 135146.

Jacovides C.P., Kaltsounides N.A., Assimakopoulos D.N. and Kaskaoutis D.G., 2005. Spectral aerosol optical depth and Angström parameters in the polluted Athens atmosphere. Theoretical and Applied Climatology 81, 161167.

Janjai S., Kumharn W. and Laksanaboonsong J., 2003. Determination of Angström's turbidity coefficient over Thailand. Renewable Energy 28, 16851700 .

Karayel M., Navvab M., Ne'eman E. and Selkowitz S., 1984. Zenith luminance and sky luminance distributions for daylighting calculations. Energy and Buildings 6(3), 283-291.

Kaskaoutis D.G. and Kambezidis H.D., 2008a. The choice of the most appropriate aerosol model in a radiative transfer code. Solar Energy 82, 11981208.

Kaskaoutis D.G. and Kambezidis, H.D., 2008b. The role of aerosol models of the SMARTS code in predicting the spectral direct-beam irradiance in an urban area. Renewable Energy 33, 1532-1543.

Kasten F., 1980. A simple parameterization of the pyrheliometric formula for determining the Linke turbidity factor. Meteor. Rundschau 33, 124-127.

Kasten F., 1996. The Linke turbidity factor based on improved values of the integral ayleigh optical thickness. Solar Energy 56, 239-244.

Kasten F., 1988. Elimination of the virtual diurnal variation of the Linke turbidity factor. Meteor. Rdsch. 41, 93-94.

Leckner, B., The spectral distribution of solar radiation at the earth's surface -
Elements of a model. Solar Energy 20, 143-150.

Linke F., 1922. Transmissions Koeffizient und Trübungsfaktor. Beitrüge zur Physik der Atmosphére 10, 91-103.

Long, C.N., and Ackerman, T.P., 2000. Identification of clear skies from broadband pyranometer measurements and calculation of downwelling shortwave cloud effects, Journal of Geophysical Research, 105, 609-626.

Lopez, G. and Batlles, F.J., 2004. Estimate of the atmospheric turbidity from three broad-band solar radiation algorithms, a comparative study. Annales Geophysicae 22, 2657-2668.

Louche A., Peri G. and Iqbal M. (1986) An analysis of Linke turbidity factor. Solar Energy 37 (6), 393.

Malik A.Q., 2000. A modified method of estimating Angström's turbidity coefficient of solar radiation models. Renewable Energy 21, 537-552.

Masmoudi M., Chaabane M., Tanré D., Gouloup P., Blarel L. and Elleuch F., 2003. Spatial and temporal variability of aerosol: size distribution and optical properties. Atmospheric Research 66 (1-2), 1-19.

Mavromatakis F. and Franghiadakis Y., 2007. Direct and indirect determination of the Linke turbidity coefficient. Solar Energy 81, 896-903.

Pinazo J.M., Canada J. and Boscá J.V., 1995. A new method to determine the Angström's turbidity coefficient: its application to Valencia. Solar Energy 54, 4, 219-226.

Trabelsi A. and Masmoudi M., 2011. An investigation of atmospheric turbidity over Kerkennah Island in Tunisia. Atmospheric Research 101, 22-30.

Vida J., Foyo-Moreno I. and Alados-Arboledas L., 1999. Performance validation of MURAC, a cloudless sky radiance model proposal. Energy 24, 705-721.

Wen C.C. and Yeh H.H., 2009. Analysis of atmospheric turbidity levels at Taichung Harbor near the Taiwan. Atmospheric Research 94, 168-177.

Zakey A.S., Abdelwahab M.M. and Maka P.A., 2004. Atmospheric turbidity over Egypt. Atmospheric Environment 38, 1579-1591.

\section{Appendix}

The temporal variations of the Linke turbidity factor and the Angström turbidity coefficient for each year are fitted with sixth order polynomial functions (see Figure 5). The coefficients $a_{i}$ $(i=0,1, \ldots, 6)$ of these polynomial functions are given in Table 3 for the Linke turbidity factor and in Table 4 for the Angström turbidity coefficient (high index correspond to high degrees). These coefficients assume that the unit of the date is the year. The predicted value of each parameter will be adjusted to the required accuracy. 